\title{
Effect of Glucose Deprivation on Sulfatide Synthesis and Oligodendrocytes in Cultured Brain Cells of Newborn Mice
}

\author{
K. ZUPPINGER, ${ }^{(44)}$ U. WIESMANN, H. P. SIEGRIST, T. SCHÄFER, L. SANDRU, H. P. SCHWARZ, \\ AND N. HERSCHKOWITZ \\ Department of Pediatrics, University of Berne, Berne, Switzerland
}

\begin{abstract}
Summary
The present work was designed to develop a model for studying the effect of substrates on brain cell metabolism. The synthesis of sulfatide, a myelin lipid, which takes place predominantly in oligodendrocytes was measured in vitro in dissociated cell cultures of newborn mouse brains at $\mathbf{1 3}$ days in culture. This corresponds to an active stage of in vivo myelination. The effect of increasing durations of severe glucose deprivation (below $1 \mathrm{mM}$ in the medium) was assessed on morphology, cellular protein, DNA, sulfatide synthesis, cerebroside sulfotransferase activity, and mucopolysaccharide synthesis.

Glucose was rapidly consumed by the cultured cells above a concentration of $0.4 \mathrm{mM}$ in the medium. At high and intermediate glucose concentrations, between 43.8 and $63.6 \%$ of the glucose consumed was accumulated as lactate on a molar ratio, indicating that the pyruvate dehydrogenase complex was rate limiting. In severe glucose deprivation, lactate consumption of the cultures exceeded accumulation.

With increasing duration of severe glucose deprivation (below $1 \mathrm{mM}$ ), the following major changes were observed. The number of phase dark cells identified by immunofluorescence as oligodendrocytes progressively decreased. Immunologically identified astrocytes apparently were unaffected by glucose deprivation. Sulfatide synthesis progressively dropped to $3.8 \%$ of control, and cerebroside sulfotransferase dropped to $10.3 \%$ of control with prolonged glucose deprivation. Thus, oligodendrocytes and one of their specific functions were damaged by glucose deprivation.

Lactate, in spite of its being consumed by the brain cell cultures, was unable to replace glucose as a substrate for sulfatide synthesis.

Uninfluenced by glucose deprivation were total cellular phosphocreatinkinase, arylsulfatase $\mathrm{A}$, as well as total mucopolysaccharide synthesis by the brain cell cultures.
\end{abstract}

\section{Speculation}

The present study shows that sulfatide synthesis in cultured brain cells of newborn mice at a stage corresponding to active in vivo myelination is dependent upon availability of glucose. Lactate, in spite of its being consumed by the brain cells, is unable to replace glucose with respect to sulfatide synthesis. This system of cultivated brain cells may serve as a model for studying other potential fuels for the maintenance of oligodendrocyte function.

Hypoglycemia may cause permanent brain damage especially in the newborn period $(10,20,31)$. This is reflected in diffuse histopathologic changes of brain morphology with degeneration of neurones $(2,4)$. However, specific lesions which may be attrib- uted exclusively to hypoglycemia could not be defined. Hypoglycemia in the newborn is usually accompanied by secondary phenomena, such as hypoxia, circulatory failure, or toxic influences due to infections, all of which may lead to brain damage per se.

Brain changes in animals induced by experimental hypoglycemia showed a decrease of brain weight with decreased total protein and DNA in young rats (8), swelling of neurones and oligodendroglia with only mild swelling of astrocytes in rat brains (18). and cortical changes in rhesus monkeys $(19,30)$. Metabolic consequences of hypoglycemia in animals comprise alterations in brain aminoacids $(25,41)$, glucose and glycogen $(8,25)$ and glycolytic as well as citric acid cycle intermediates (25). The brain high-energy phosphates were depleted only at marked hypoglycemia (26). The membrane lipids cholesterol and phospholipid were diminished (8). Brain cerebroside as well as sulfate incorporation into the myelin lipid sulfatide was also reduced, whereas lipid $\mathrm{N}$-acetyl-neuraminic acid as a measure of gangliosides located in neurones was not altered by hypoglycemia (8).

The purpose of the present work was to characterize the effect of glucose deprivation on a specific step in structural brain metabolism during early development. Sulfatide synthesis (SFS) was chosen as a specific function of oligodendrocytes which plays a central role in myelination. A standardized system of cultured brain cells from newborn mice was utilized which shows an agedependent SFS comparable to the in vivo development (42). This system makes it possible to study directly the effects of glucose changes on brain cell metabolism, avoiding changes at the blood brain barrier and secondary humoral, circulatory, or respiratory influences.

\section{MATERIALS AND METHODS}

\section{CELL CULTURES}

Brain cells were obtained from newborn mice (Swiss albino: Hoffmann-La Roche, Inc., Basel, Switzerland) within $12 \mathrm{hr}$ after birth. Dissociation of the cells was achieved as previously described (42) but without trypsinisation. Aliquots of $15.0 \pm 0.14$. $10^{6}$ cells counted in a coulter counter (Industrial D: Harpenden, Herts, United Kingdom) were seeded into $100 \mathrm{~mm}$ plastic culture plates (Corning Glass Works, Corning, New York) containing a final volume of $10 \mathrm{ml}$ of Dulbecco's modified Eagle's medium with $10 \%$ fetal calf serum. Penicillin G, sodium salt was added at 100 units $/ \mathrm{ml}$. The medium was enriched with l-glutamine $0.5 \mathrm{~g} /$ liter, buffered to $\mathrm{pH} 7.5$ by $\mathrm{NaHCO}_{3,}$, and equilibrated by $5 \% \mathrm{CO}$ and $95 \%$ air in gas-tight plastic boxes. A high initial cell number was chosen because it favors the development of brain cells in vitro as had been shown by others $(5,36)$. 
The initial concentration of glucose in the medium was $25.2 \pm$ $2.0 \mathrm{mM}$, and that of lactate was $1.97 \pm 0.16 \mathrm{mM}$. The lactate originated from the fetal calf serum. The cells were allowed to settle and were incubated at $37^{\circ} \mathrm{C}$ for 6 days without interference. At 6 and 8 days in culture (DIC), the medium was replaced by fresh medium of the same composition. The cells were confluent at 8 DIC. The cell count after trypsinisation was followed in preliminary experiments. It dropped to $4.5 \pm 1.1 \cdot 10^{6}$ cells/plate at 6 DIC and remained at $4.9 \pm 1.1 \cdot 10^{6}$ cells/plate at $13 \mathrm{DIC}$.

\section{EXPERIMENTAL PROCEDURE}

At 10 DIC, the medium was renewed by adding fresh medium containing specific concentrations of glucose (group $A$ to $F$ had $25.2,13.2,7.3,4.8,2.8$, and $0.8 \mathrm{mM}$ initial glucose). At $13 \mathrm{DIC}$, aliquots of medium were removed and kept frozen at $-20^{\circ} \mathrm{C}$ until analyzed. The tubes for glucose analysis contained $\mathrm{NaF}(2 \mathrm{mg} /$ $\mathrm{ml}$ ). Thereafter, carrier-free $\mathrm{H}_{2}{ }^{35} \mathrm{SO}_{4}$ (The Radiochemical Center, Amersham, United Kingdom) $20 \mu \mathrm{Ci} / \mathrm{ml}$ medium was added to the cultures, and the incubation continued for another $24 \mathrm{hr}$. The medium was then removed and the cells were washed twice with $10 \mathrm{ml} 0.9 \% \mathrm{NaCl}$ solution, harvested with a rubber policeman, washed again, centrifuged, and kept frozen at $-20^{\circ} \mathrm{C}$ until analyzed. Before analysis, the cells were homogenised by ultrasonication for $30 \mathrm{sec}$ at $30 \mathrm{~W}$.

\section{ANALYTICAL PROCEDURES}

Cellular protein was measured chemically (27), and DNA was measured fluorometrically (15). Glucose was determined by a hexokinase method (33); lactate and phosphocreatinkinase were determined enzymatically (33). Arylsulfatase A was determined as previously described (42).

Incubation of media containing glucose or lactate for $72 \mathrm{hr}$ under the same conditions but without cells did not alter the concentrations of these substrates. Incorporation of ${ }^{35} \mathrm{SO}_{4}$ into sulfatide was measured after lipid extraction as previously described (42). Using the same system, ${ }^{35} \mathrm{SO}_{4}$-sulfatide was identified by thin-layer chromatography (14). The cellular homogenates were analyzed for cerebroside sulfotransferase (EC 2.8.2.11) as previously described (37). The assay system contained $100 \mu \mathrm{g}$ protein suspension, 300,000 dpm PAP ${ }^{35} \mathrm{~S}$ (New England Nuclear, Dreieichenhain, Federal Republic of Germany) in $100 \mu 10.9 \%$ $\mathrm{NaCl}$ solution and $200 \mu \mathrm{l} 100 \mathrm{mM}$ imidazole- $\mathrm{HCl}$ buffer, $20 \mathrm{mM}$ $\mathrm{MgCl}_{2}, 200 \mathrm{mM} \mathrm{NaCl}(\mathrm{pH} \mathrm{7.0)}, 50 \mu \mathrm{g}$ cerebroside in $0.9 \% \mathrm{NaCl}$. Cerebrosides were dissolved in chloroform:methanol, 2:1, dried in an all glass homogenizer, appropriate amounts of $0.9 \% \mathrm{NaCl}$ solution were added, and the mixture was homogenized at 800 $\mathrm{rpm}$ for $1 \mathrm{~min}$. The suspension was then sonicated for $10 \mathrm{~min}$ in a sonication bath at $0^{\circ} \mathrm{C}$ and used immediately after preparation. The determinations were carried out at $30^{\circ} \mathrm{C}$ for $20 \mathrm{~min}$ without solubilization of the enzyme by Triton.

Macromolecularly bound ${ }^{35} \mathrm{SO}_{4}$ in the medium considered as mucopolysaccharides secreted by the cells (42) was measured in aliquots of medium after dialysation for $4 \mathrm{hr}$ against $0.01 \mathrm{M}$ $\left(\mathrm{NH}_{4}\right)_{2} \mathrm{SO}_{4}$ and subsequently for $12 \mathrm{hr}$ against water. Cellular ${ }^{35} \mathrm{SO}_{4}$-mucopolysaccharide formation was determined after lipid extraction in the cellular residuum which was dissolved in $2 \mathrm{~N}$ $\mathrm{NaOH}$ at $70^{\circ} \mathrm{C}$ for $10 \mathrm{~min}$ (11). The counting of radioactivity was done in a Packard Tricarb scintillation counter equipped with an automatic activity analyser (model 3380; Packard Instrument Co., Downers Grove, IL).

For statistical analysis, a two-tailed Student $t$ test was used. A total of 42 separate incubation experiments, each comprising 12 to 24 plates, was performed with duplicate or triplicate cultures for each value. The extractions were performed in duplicate, and the mean value was taken for statistical calculations. All values given are expressed as mean \pm standard error.

The timed pregnancy Swiss albino mice were generously supplied by Hoffmann-La Roche. The modified Dulbecco Eagle's medium without glucose, and the fetal calf serum were obtained from Seromed GmbH, Munich Federal Republic of Germany.
$\mathrm{D}(+)$ glucose, monohydrate was purchased from E. Merck, Darmstadt Federal Republic of Germany, and L-lactate was purchased from Boehringer GmbH, Mannheim, Federal Republic of Germany.

\section{IMMUNOLOGIC IDENTIFICATION OF CELLS}

An indirect immunofluorescence assay was used for cellular identification (17). For this purpose, cells were separately cultured for 13 days on glass coverslips and fixed with $3.7 \%$ formaldehyde for $15 \mathrm{~min}$. Thereafter, $3.7 \%$ formaldehyde plus $0.2 \%$ Triton $\mathrm{X}$ 100 was added for another $15 \mathrm{~min}$ when $50 \%$ acetone, $100 \%$ acetone, and 50\% acetone were applied sequentially for $3 \mathrm{~min}$ each at $4^{\circ} \mathrm{C}$. After washing with phosphate-buffered saline, the cultures were incubated for $30 \mathrm{~min}$ at $20^{\circ} \mathrm{C}$ with rabbit antiserum (diluted 1/30) directed against galactocerebroside (GC) which is considered a marker for oligodendrocytes in culture (32), or with rabbit antiglial fibrillary acidic protein serum (diluted 1/30) for identification of astrocytes (6). As a control, preimmunisation serum was used but never gave a positive reaction. In a second step, the slides were stained with a fluoresceine-isothiocyanatelabeled goat antirabbit immunoglobulin G serum (Cappel laboratories), mounted in buffered glycerol, and examined under ultraviolet light by using a Wild Leitz Orthoplan microscope.

\section{RESULTS}

\section{GLUCOSE CONSUMPTION}

The glucose concentrations in the media declined rapidly between days 10 and 13 in all groups (Fig. 1), indicating that the mouse brain cells were avidly consuming glucose. The steepest decline occurred during the first day after the addition of fresh specific medium. This initial glucose consumption was independent of the glucose concentration above $1 \mathrm{mM}(=18 \mathrm{mg} \%)$ and ranged between $16.3 \pm 0.5$ and $19.6 \pm 1.0 \mu$ moles $/ \mathrm{mg}$ cellular protein per $24 \mathrm{hr}$ in groups A to D. Final glucose concentrations remained above $15 \mathrm{mM}(=270 \mathrm{mg} \%)$ in group $A$ and above 2.7 $\mathrm{mM}(=50 \mathrm{mg} \%)$ in group B. In all other groups, severe glucose deprivation below $1 \mathrm{mM}$ was eventually reached and lasted for 24 to $72 \mathrm{hr}$ in groups $\mathrm{C}$ to $\mathrm{F}$, respectively. The glucose deprivation below $1 \mathrm{mM}$ was eventually reached and lasted for 24 to $72 \mathrm{hr}$ in

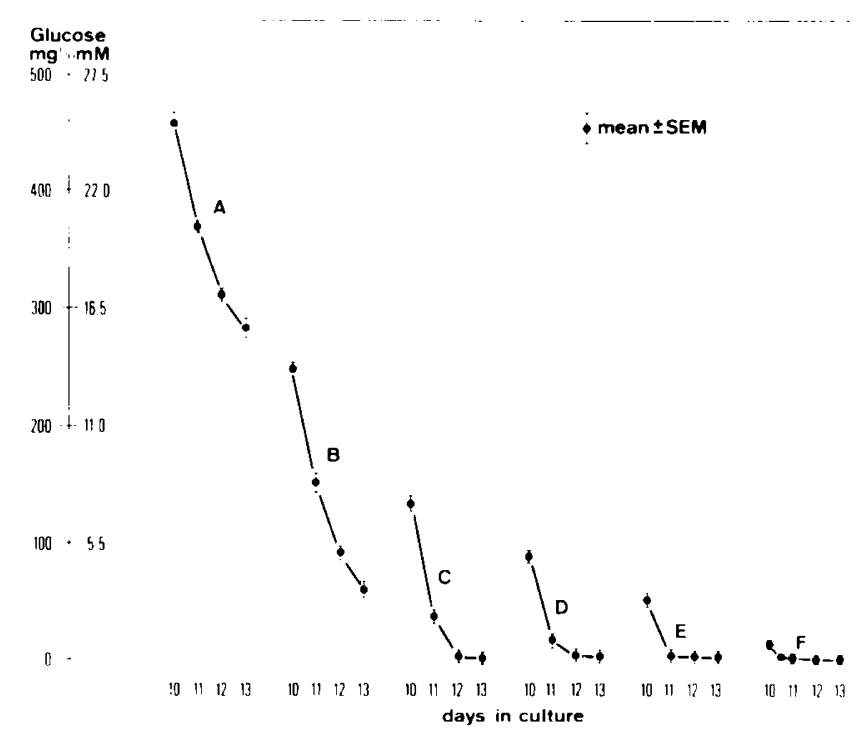

Fig. 1. Glucose changes in media of mouse brain cell cultures between days 10 and 13 in culture. The initial glucose levels in the media were: group A $(n=27), 25.2 \mathrm{mM}$; group $\mathrm{B}(n=13), 13.2 \mathrm{mM}$; group C $(n=12)$, $7.3 \mathrm{mM}$; group $\mathrm{D} \cdot(n=12), 4.8 \mathrm{mM}$; group $\mathrm{E}(n=14), 2.8 \mathrm{mM}$; group $\mathrm{F}$ $(n=10), 0.8 \mathrm{mM}$. The duration of severe glucose depletion (below $1 \mathrm{mM}$ ) was approximately $24 \mathrm{hr}$ in group C, $36 \mathrm{hr}$ in group D, $48 \mathrm{hr}$ in group E, and $72 \mathrm{hr}$ in group $\mathrm{F}$. 
groups $\mathrm{C}$ to $\mathrm{F}$, respectively. The glucose decline from an initial level of $1.0 \mathrm{mM}$ was followed in two additional experiments at hourly intervals (data not shown), revealing a linear decline to 0.4 $\mathrm{mM}$ after $12 \mathrm{hr}$ with no further change thereafter, indicating that the cells were incapable of further glucose extraction below a minimal glucose concentration of approximately $0.4 \mathrm{mM}$.

\section{LACTATE CHANGES}

In the experiments with high or intermediate initial glucose levels (groups $\mathrm{A}$ to $\mathrm{D}$ ), the lactate concentration rose during incubation as a function of the initial glucose level (Table 1). In groups $A$ and $B$, lactate production was highest with more than one-half of the glucose consumed accumulating as lactate on a molar ratio (Table I, last column). At low initial glucose concentration, lactate did not accumulate (group E) and even disappeared from the medium when the cultures were kept in severe glucose deprivation for most of the incubation period (group F).
EFFECTS OF GLUCOSE DEPLETION ON CELLULAR VARIABLES

The morphology of the cultures up to 10 days during incubation in glucose-containing media was similar to that originally described (42). The cultures contained at least two layers of cells; phase translucent cells in the basal layer were identified in a large part as astrocytes by antiglial fibrillary acidic protein serum (Fig. 2) and small phase dark cells situated in the top layer identified as oligodendrocytes by anti-GC serum (Fig. $3 A$ ). Glucose deprivation between days 10 and 13 had clear effects on morphology of the cultures. With progressive glucose deprivation, the number of phase dark cells identified as oligodendrocytes was strongly decreased (Fig. 3, $C$ and $F$ ), whereas the staining of astrocytes was apparently not affected by glucose deprivation (not shown). Quantitative assessment of GC-positive cells expressed as cell number per $0.25 \mathrm{~mm}^{2}$ of culture surface chosen randomly at different initial glucose concentrations gave the following results: at 25.2 $\mathrm{mM}(A), 58.6 \pm 3.5 ;$ at $7.3 \mathrm{mM}(C), 26.8 \pm 1.5 ;$ at $0.8 \mathrm{mM}(F), 7.1$ \pm 1.5 (values given as mean \pm S.E., $n=8$, at each concentration).

Table 1. Lactate accumulation in the medium in relation to glucose consumption by mouse brain cell cultures (days 10 to 13 in culture) ${ }^{1}$

\begin{tabular}{|c|c|c|c|c|c|c|}
\hline $\begin{array}{l}\text { Experi- } \\
\text { mental } \\
\text { group }\end{array}$ & $(n)$ & $\begin{array}{l}\text { Initial } \\
\text { glucose } \\
(\mathrm{mM})\end{array}$ & $\begin{array}{l}\text { Lactate changes } \\
\text { (mmoles/72 } \mathrm{hr} \text { ) }\end{array}$ & $\begin{array}{l}\text { Lactate accumulation } \\
\text { ( } \mu \text { moles } / \mathrm{mg} \text { cell } \\
\text { protein } / 72 \mathrm{hr})\end{array}$ & $\begin{array}{l}\text { Glucose consumption } \\
\text { ( } \mu \text { moles } / \mathrm{mg} \text { cell } \\
\text { protein } / 72 \mathrm{hr})\end{array}$ & $\begin{array}{l}\text { Lactate accumulated in } \% \text { of } \\
\text { glucose consumption } \\
\text { (molar ratio) }\end{array}$ \\
\hline A & (14) & 25.2 & $\begin{array}{c}+13.18 \pm 0.54^{2} \\
\text { n.s. }{ }^{3}\end{array}$ & $\begin{array}{c}38.6 \pm 1.5 \\
\text { n.s. }\end{array}$ & $\begin{array}{l}34.3 \pm 0.9 \\
P<0.01\end{array}$ & $\begin{array}{c}56.8 \pm 2.8 \\
\text { n.s. }\end{array}$ \\
\hline B & (13) & 13.2 & $\begin{array}{l}+13.36 \pm 0.49 \\
P<0.001\end{array}$ & $\begin{array}{l}39.4 \pm 2.5 \\
P<0.001\end{array}$ & $\begin{array}{l}30.8 \pm 0.8 \\
P<0.001\end{array}$ & $\begin{array}{l}63.9 \pm 3.6 \\
P<0.001\end{array}$ \\
\hline C & $(10)$ & 7.3 & $\begin{array}{l}\quad+5.64 \pm 0.63 \\
P<0.05\end{array}$ & $\begin{array}{l}17.2 \pm 2.2 \\
\text { n.s. }\end{array}$ & $\begin{array}{c}21.6 \pm 0.7 \\
\text { n.s. }\end{array}$ & $\begin{array}{c}39.1 \pm 4.3 \\
\text { n.s. }\end{array}$ \\
\hline D & $(12)$ & 4.8 & $\begin{array}{l}\quad+4.09 \pm 0.35 \\
P<0.001\end{array}$ & $\begin{array}{l}19.6 \pm 2.2 \\
P<0.001\end{array}$ & $\begin{array}{l}21.9 \pm 0.7 \\
P<0.001\end{array}$ & $43.8 \pm 3.8$ \\
\hline E & (11) & 2.8 & $\begin{array}{l}\quad+0.08 \pm 0.22 \\
P<0.00 \mathrm{I}\end{array}$ & $\begin{aligned} & 0.5 \pm 1.1 \\
& P<0.001\end{aligned}$ & $\begin{array}{l}10.6 \pm 0.8 \\
P<0.001\end{array}$ & \\
\hline $\mathrm{F}$ & $(10)$ & 0.8 & $-1.25 \pm 0.14$ & $-4.4 \pm 0.5$ & $2.8 \pm 0.1$ & \\
\hline
\end{tabular}

' Significance of difference between experimental groups.

${ }^{2}$ Mean \pm S.E.

${ }^{3}$ n.s., not significant.
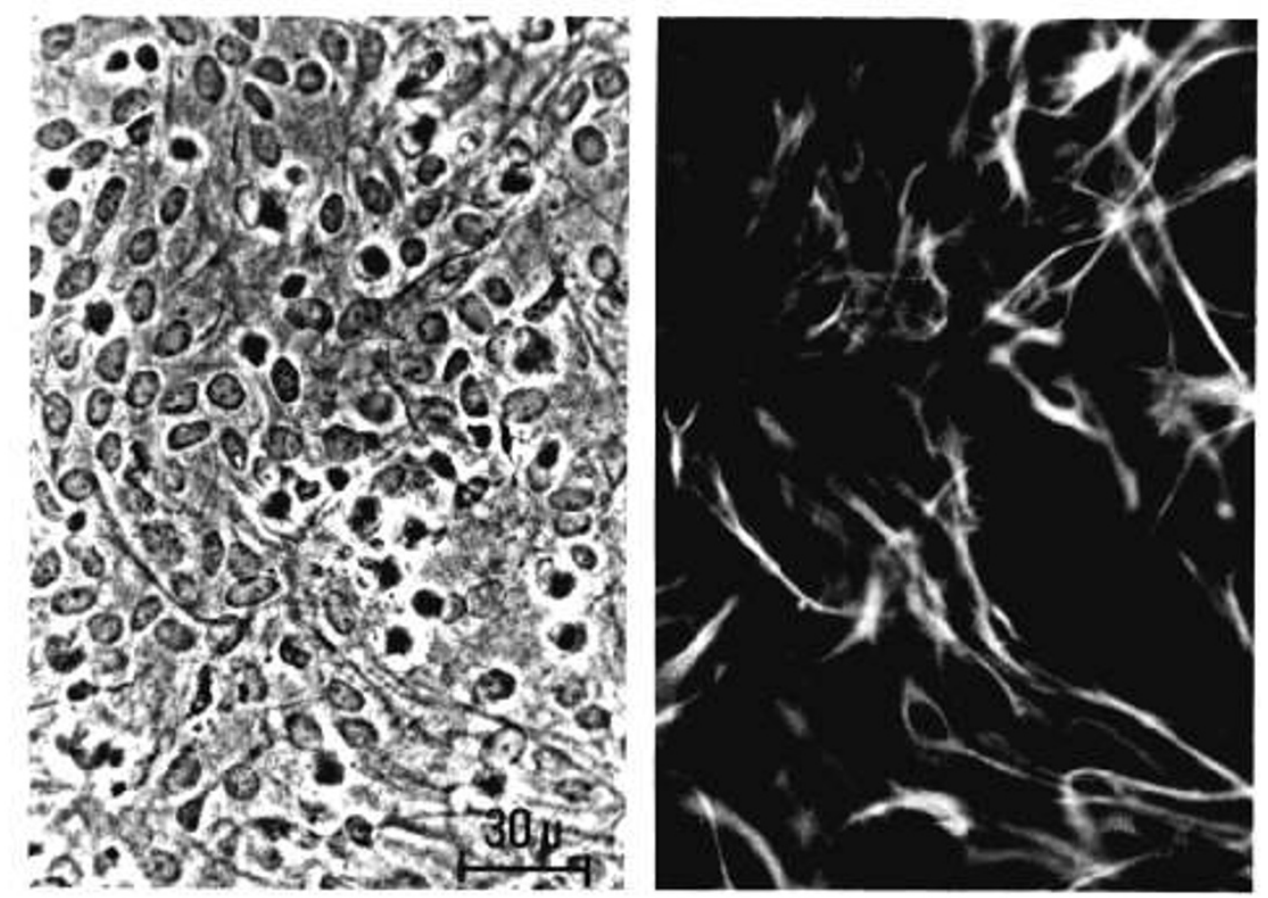

Fig. 2. Identification of astrocytes in mouse brain cell cultures at 13 DIC in phase contrast (left) and in immunofluorescence staining (right). The phase translucent cells in the bottom layer were identified to a large part of astrocytes by antiglial fibrillary acidic protein serum. In the top layer, small phase dark cells are visible which were identified as oligodendrocytes by GC serum as seen in Figure 3. 

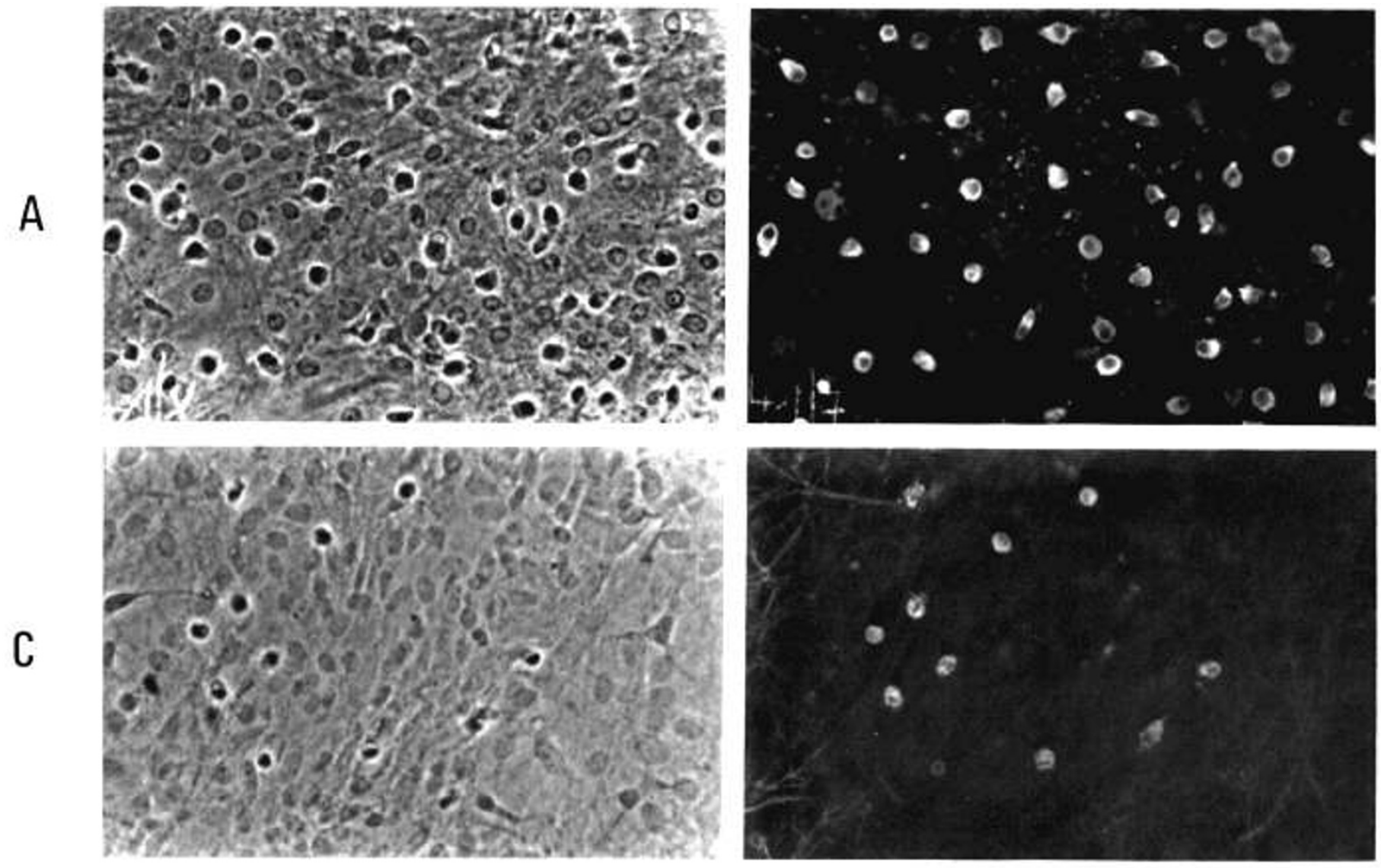

F
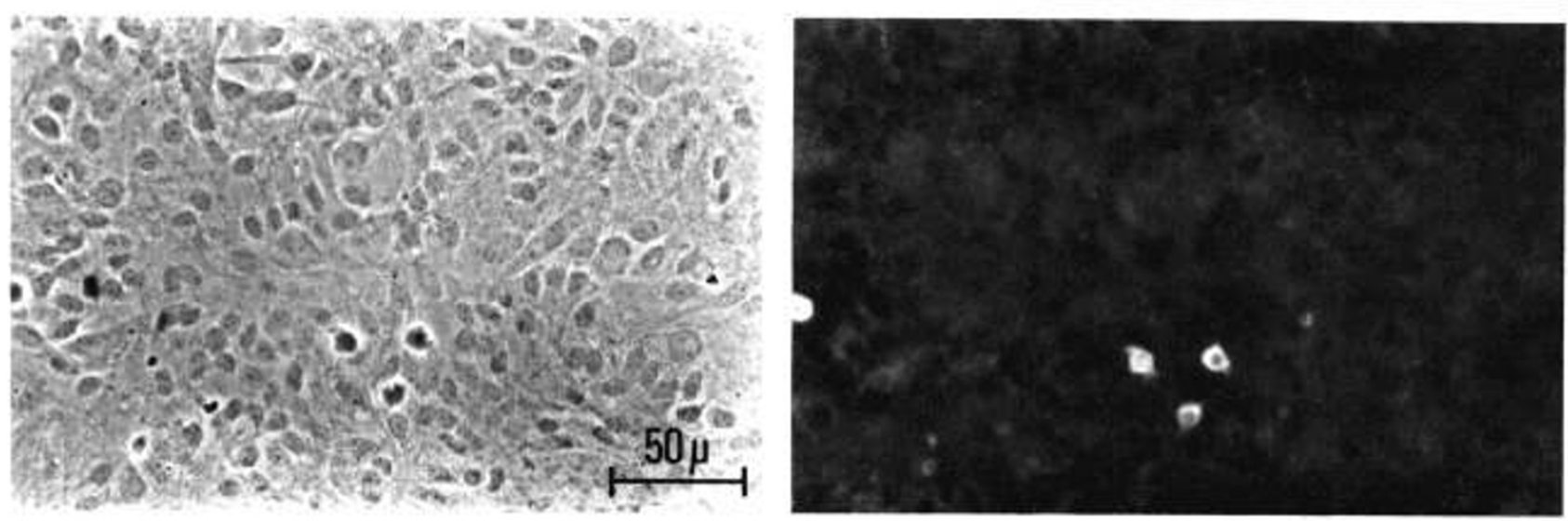

Fig. 3. Morphologic changes in mouse brain cell cultures at 13 DIC kept under different glucose concentrations between days 10 and 13 in culture Phase contrast (left) and immunostaining with anti-GC serum (right). Initial glucose concentrations: $25.2 \mathrm{mM}(A), 7.3 \mathrm{mM}(C)$, and $0.8 \mathrm{mM}(F)$.

Progressive disappearance of phase dark cells in the top layer identified as oligodendrocytes with increasing glucose deprivation.

The difference between the three groups was highly significant $(P$ $<0.001)$.

The total cellular protein and DNA of the whole cultures was reduced in relation to glucose deprivation (Table 2), whereas the mean cellular mass as judged from the protein/DNA ratio increased. With the current methodology, it was not possible to differentiate which cells contribute to the changes in protein/ DNA ratios.

EFFECT OF GLUCOSE DEPRIVATION ON SULFATIDE SYNTHESIS AND CEREBROSIDE SULFOTRANSFERASE ACTIVITY

SFS assessed as ${ }^{35} \mathrm{SO}_{4}$ incorporation into cellular sulfatide was clearly dependent upon the initial glucose level and thus upon the degree and duration of glucose deprivation (Fig. 4). In groups A and $B$ which were kept under high glucose concentrations, SFS was not significantly different. With prolongation of severe glucose deprivation (below I $\mathrm{mM}$ ), SFS was progressively and significantly decreased.
Table 2. Total cellular protein and DNA of mouse brain cultures in relation to glucose deprivation ${ }^{1}$

\begin{tabular}{cccccc}
$\begin{array}{c}\text { Experi- } \\
\text { mental } \\
\text { group }\end{array}$ & $(n)$ & $\begin{array}{c}\text { Initial } \\
\text { glucose } \\
(\mathrm{mM})\end{array}$ & $\begin{array}{c}\text { Protein } \\
(\mathrm{mg} / \text { plate })\end{array}$ & $\begin{array}{c}\text { DNA }(\mu \mathrm{g} / \\
\text { plate })\end{array}$ & $\begin{array}{c}\text { Protein/ } \\
\text { DNA } \cdot 10^{2}\end{array}$ \\
\hline A & $(30)$ & 25.2 & $2.96 \pm 0.11^{2}$ & $300 \pm 17$ & $1.02 \pm 0.03$ \\
B & $(15)$ & 13.2 & $3.31 \pm 0.18$ & $353 \pm 19$ & $0.95 \pm 0.04$ \\
C & $(15)$ & 7.3 & $3.26 \pm 0.12$ & $285 \pm 17$ & $1.17 \pm 0.04$ \\
& & & & & $P<0.01$ \\
D & $(12)$ & 4.8 & $2.17 \pm 0.07$ & $190 \pm 7$ & $1.15 \pm 0.04$ \\
& & & $P<0.001$ & $P<0.001$ & $P<0.05$ \\
E & $(14)$ & 2.8 & $2.72 \pm 0.15$ & $232 \pm 16$ & $1.20 \pm 0.03$ \\
& & & & $P<0.05$ & $P<0.01$ \\
F & $(14)$ & 0.8 & $2.56 \pm 0.13$ & $230 \pm 15$ & $1.16 \pm 0.06$ \\
& & & $P<0.05$ & $P<0.05$ & $P<0.05$ \\
\hline
\end{tabular}

'Significance of difference from group $A$.

${ }^{2}$ Mean \pm S.E. 
The microsomal enzyme cerebroside sulfotransferase activity (CST) responsible for sulfation of cerebroside to form sulfatide showed a clear dependence of its activity upon glucose availability (Table 3) with a sharp and significant drop shown in the experiments with prolonged glucose deprivation (groups $\mathrm{C}$ to $\mathrm{F}$ ). Comparison of the relative values of CST activity with SFS (Table 3) showed a roughly parallel decrease. CST activity still persisted at about $10 \%$ of the controls in spite of long-lasting glucose deprivation in groups $\mathrm{E}$ and $\mathrm{F}$ whereas SFS was virtually abolished.

\section{EFFECT OF LACTATE ON SFS}

In a separate experiment, SFS was measured at increasing concentrations of lactate with low initial glucose levels to see whether lactate could serve as an alternate substrate in respect to

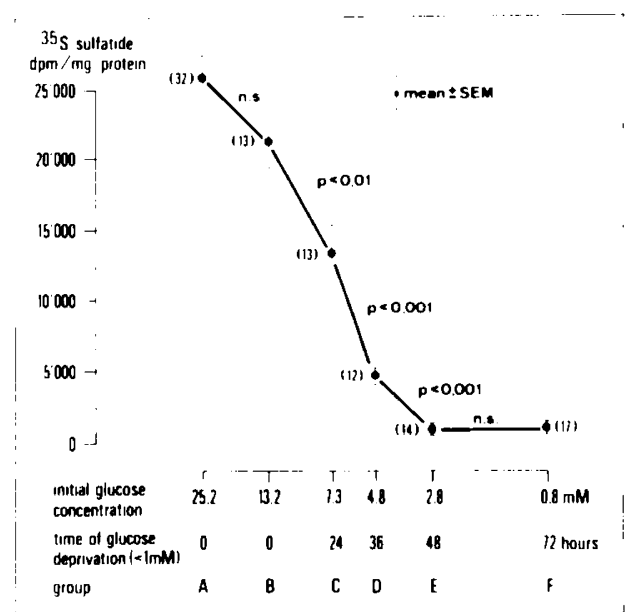

Fig. 4. Dependence of SFS in mouse brain cell cultures upon the initial glucose concentration in the medium and the duration of severe glucose deprivation (below $1 \mathrm{mM}$ ). respectively. SFS was measured as ${ }^{35} \mathrm{~S}$-sulfatide in brain cells at day 14 in culture. The values were obtained in the same cultures as the ones in Figure 1.
SFS (Table 4). Yet SFS was below $1 \%$ at any lactate concentration in comparison to the controls with $25.2 \mathrm{mM}$ initial glucose. Thus, SFS was not sustained in glucose deprivation by the addition of lactate in spite of the fact that the cultures were consuming lactate at increasing rates with increasing initial lactate availability (Table 4).

\section{EFFECT OF GLUCOSE DEPRIVATION ON MUCOPOLYSACCHARIDES} (MPS)

In spite of the marked effect of glucose deprivation on sulfate incorporation into sulfatide neither synthesis of ${ }^{35} \mathrm{SO}_{4}$-MPS nor secretion of MPS into the medium was influenced by reduction of glucose supply (Table 5 ). In separate experiments, the influence of the duration of severe glucose deprivation (initial glucose, 0.8 $\mathrm{mM}$ ) on ${ }^{335} \mathrm{SO}_{4}$-MPS synthesis and secretion was studied, again showing no effect up to $72 \mathrm{hr}$ of incubation (data not shown).

\section{DISCUSSION}

\section{GLUCOSE CONSUMPTION}

Dissociated brain cell cultures of chicken embryo origin rapidly remove glucose from the incubation medium (21), but the rate of

Table 5. Effect of glucose on MPS synthesis and secretion into the medium

\begin{tabular}{|c|c|c|c|c|}
\hline $\begin{array}{l}\text { peri- } \\
\text { ental } \\
\text { roup }\end{array}$ & $(n)$ & $\begin{array}{l}\text { Initial } \\
\text { glucose } \\
\text { (mM) }\end{array}$ & $\begin{array}{l}\text { Synthesis of }{ }^{\mathrm{s}} \mathrm{SO}_{1^{-}} \\
\text {MPS (dpm/mg protein } \\
\text { of lipid free cell } \\
\text { residue) }\end{array}$ & $\begin{array}{l}\text { Secretion of }{ }^{-S}{ }_{1-} \\
\text { MPS }(\mathrm{dpm} / 10 \mathrm{ml} \\
\text { medium } / \mathrm{mg} \text { cell } \\
\text { protein })\end{array}$ \\
\hline A & (2) & 25 & 7,744 & 1.399 \\
\hline B & (2) & $13.2 x-2$ & $7.962 \pm$ & $230.218 \pm 25.788$ \\
\hline c & (3) & 7.3 & $94.643 \pm$ & $218.072 \pm 8.140$ \\
\hline D) & (2) & 4.8 & $56.006 \pm$ & $224.406 \pm 26.850$ \\
\hline $\mathrm{E}$ & (3) & 2. & & $208,776=$ \\
\hline $\mathrm{F}$ & (2) & 0.8 & $56.223 \pm 2.360$ & $225,316 \pm 12,560$ \\
\hline
\end{tabular}

Mean \pm S.E.

Table 3. Effect of glucose on cellular CST and SFS

CST

\begin{tabular}{|c|c|c|c|c|c|}
\hline $\begin{array}{l}\text { Experimental } \\
\text { group }\end{array}$ & $\begin{array}{l}\text { Initial glucose } \\
(\mathrm{mM})\end{array}$ & $\begin{array}{c}\mathrm{dpm} \\
{ }^{\mathrm{S}} \mathrm{SO}_{1} \text {-sulfatide } \\
\text { Mean } \pm \text { S.E. }\end{array}$ & $\begin{array}{l}\text { protein } \\
(n)\end{array}$ & $\begin{array}{l}\text { Relative value } \\
\text { (\%) }\end{array}$ & $\begin{array}{c}\text { SFS as }{ }^{55} \mathrm{SO}_{1} \text { incorporation into sulfatide } \\
\text { relative value }(\%)\end{array}$ \\
\hline A & 25.2 & $\begin{array}{l}24.894 \pm 1,676^{2} \\
\text { n.s. }\end{array}$ & (13) & 100 & 100 \\
\hline B & 13.2 & $\begin{array}{l}27,175 \pm 2,968 \\
P<0.001\end{array}$ & (7) & 109.2 & 82.4 \\
\hline C & 7.3 & $\begin{aligned} & 7,288 \pm 1,557 \\
& P<0.05\end{aligned}$ & (5) & 29.3 & 51.3 \\
\hline D & 4.8 & $\begin{array}{l}3.823 \pm 445 \\
\text { n.s. }\end{array}$ & (8) & 15.4 & 17.9 \\
\hline E & 2.8 & $\begin{array}{l}2.194 \pm 342 \\
\text { n.s. }\end{array}$ & (5) & 8.8 & 3.5 \\
\hline $\mathrm{F}$ & 0.8 & $2,561 \pm 352$ & (9) & 10.3 & 3.8 \\
\hline
\end{tabular}

' Significance of difference between experimental groups.

${ }^{2}$ Mean \pm S.E.

Table 4. Effect of lactate on SFS by mouse brain cell cultures (day's 10 to 13 in culture)

\begin{tabular}{|c|c|c|c|c|c|}
\hline $\begin{array}{l}\text { Initial glucose } \\
\qquad(\mathrm{mM})\end{array}$ & $\begin{array}{l}\text { Initial lactate } \\
\qquad(\mathrm{mM})\end{array}$ & $\begin{array}{l}\text { Final lactate } \\
\quad(\mathrm{mM})\end{array}$ & $\begin{array}{l}\text { Lactate consumption }(\mu \text { moles } / \mathrm{mg} \\
\text { cell protein } / 72 \mathrm{hr})\end{array}$ & $\begin{array}{l}\text { Sulfatide synthesis as }{ }^{-} \mathrm{SO} \text {, incorporation into } \\
\text { sulfatide (dpm } / \mathrm{mg} \text { cell protein) }\end{array}$ & (n) \\
\hline 25.2 & 2.1 & 13.8 & & $62.272 \pm 4.044^{\prime}$ & (3) \\
\hline 0.9 & 2.2 & 2.0 & $0.8 \pm 0.3$ & $277 \pm 67$ & (3) \\
\hline 0.9 & 4.7 & 3.5 & $3.9 \pm 0.5$ & $201 \pm 31$ & (3) \\
\hline 0.9 & 7.3 & 5.4 & $6.4 \pm 0.7$ & $366 \pm 55$ & (3) \\
\hline 1.0 & 12.7 & 9.7 & $11.2 \pm 1.0$ & $416 \pm 43$ & (3) \\
\hline 0.9 & 24.7 & 19.7 & $17.8 \pm 0.5$ & $340 \pm 61$ & (3) \\
\hline
\end{tabular}

'Mean \pm S.E. 
glucose consumption by the cells was not assessed. The present study shows that dissociated mouse brain cells also utilized glucose rapidly as long as the ambient glucose concentration remained above approximately $0.4 \mathrm{mM}$. Glucose consumption related to cellular protein was remarkably similar in our cultures to the glucose consumption of mouse brains in vivo estimated on the basis of flux measurements from blood to brain (13). Assuming the mouse brain protein content to be approximately $8 \%$ of the total wet weight $(7,29)$, the in vivo glucose consumption would amount to $0.008 \mu$ moles $\cdot \mathrm{mg}^{-1}$ protein $\cdot \mathrm{min}^{-1}$, which is only slightly lower than the mean of $0.012 \mu$ moles $\cdot \mathrm{mg}^{-1}$ protein. $\mathrm{min}^{-1}$ consumed by our brain cell cultures devoid of a blood brain barrier.

\section{LACTATE CONSUMPTION}

Because all our cultures were kept under aerobic conditions, the lactate accumulation must rather be interpreted as the consequence of a partial block of entrance into the citric acid cycle at the level of the pyruvate dehydrogenase complex which is considered to be regulatory $(39,40)$. This is reflected in our experiments by the dependence of the lactate accumulation upon the glucose supply. At high glucose provision, more than one-half of the glucose consumed appeared as lactate in the medium (Table 1). In rat brain, the activity of the pyruvate dehydrogenase complex is low at birth $(23,40,43)$, and postnatal development is slow reaching only 30 to $50 \%$ of adult activity between age 10 to 20 days $(23,40)$, whereas citric acid cycle enzymes and ketone body utilizing enzymes develop earlier (23). Studies in vivo on the basis of cerebral arteriovenous differences of the newborn rat (9) and of human newborns (22) as well as perfusion studies of early human fetal brains ( 1 ) indicated that a relevant part of the glucose taken up by the brain is released in the form of pyruvate and lactate. The accumulation of lactate by our brain cell cultures at high and intermediate glucose concentrations (Table 1, groups A to D) suggests that the activity of the pyruvate dehydrogenase complex was rate limiting for lactate consumption. In severe glucose deprivation (Tables 1 , group $F$, and 4 , group $F$ ) lactate consumption by the cultures exceeded accumulation. Cerebral lactate uptake has been observed at physiologic arterial levels in newborn baboons, and it was argued that lactate was a relevant cerebral substrate in the immediate neonatal period (24). Yet in our system lactate addition in glucose deprivation had no effect on SFS (Table 4).

\section{SFS}

Sulfate incorporation into sulfatide is considered to be a marker of cellular differentiation of oligodendrocytes cultured from dissociated newborn mouse brain cells (16). The development of SFS in this culture system roughly parallels the one in vivo as previously shown (28). The age of the cultures was chosen to fall into a phase of rapid increase of SFS (42). This period roughly corresponds to early postnatal human brain growth (12).

The main finding of the present study was a clear dependence of SFS upon glucose availability in culture. The mechanism responsible for the marked decline of SFS with prolongation of glucose deprivation could be related to morphologic changes of the cells. The decreased number of the cells identified as oligodendrocytes and the unchanged aspect of the astrocyte layer suggest a predominant damage of oligodendrocytes by glucose deprivation. Total cellular phosphocreatinkinase remained uninfluenced $(1519 \pm 27 \mathrm{IIU} / \mathrm{mg}$ protein at $25.2 \mathrm{mM}, 1944 \pm 239 \mathrm{IU}$ protein at $6.5 \mathrm{mM}$, and $2293 \pm 172 \mathrm{IU} / \mathrm{mg}$ protein at $0.8 \mathrm{mM}$ initial glucose). These findings give evidence for survival of the majority of the cells in the cultures other than oligodendrocytes.

Diminished net synthesis of sulfatide could be the consequence of either a lack of precursors, a diminished CST activity or an increased degradation. The latter possibility seems unlikely (cellular arylsulfatase $A$ was $691 \pm 40 \mathrm{nmoles} / \mathrm{hr} / \mathrm{mg}$ protein at 25.2 $\mathrm{mM}$ and $754 \pm 74 \mathrm{nmoles} / \mathrm{hr} / \mathrm{mg}$ protein at $0.8 \mathrm{mM}$ initial glucose). The marked and significant decrease of CST activity indicates that a lack of precursors was not the sole explanation for the diminution of SFS. A decrease of CST activity to $30 \%$ of control had been shown in vivo to have a profound effect on sulfatide synthesis and myelin formation $(34,35,38)$. Depletion of glucose supply to brain cells is equivalent to deprivation of their major energy fuel. The decrease of SFS thus may be caused by energy depletion. The final step of SFS consists of the formation of sulfatide from cerebroside. This reaction is catalyzed by the microsomal enzyme CST requiring activated sulfate in the form of $3^{\prime}$-phosphoadenosine- 5 '-phosphosulfate which is generated from ATP. Our observation that the synthesis of mucopolysaccharides which also requires 3 '-phosphodenosine-5'-phosphosulfate as an energy-rich precursor (3) was not influenced by glucose depletion (table 5) supports the concept that energy reserves of the whole cultures were not completely abolished even after severe glucose deprivation. In vivo studies in rats after insulin-induced hypoglycemia (25) revealed that cellular ATP and phosphocreatine remained uninfluenced by blood glucose depletion down to a level of $1 \mathrm{mM}$. Below this level, there was a sudden and marked drop of the two high energy phosphates.

The brain cultures studied contained at least two types of brain cells. A diverse sensitivity of various cell types to energy depletion might exist. Neurones could not be studied in our cultures. The astrocytes were found to be less sensitive to glucose lack than oligodendrocytes. Therefore, we have strong evidence of selective vulnerability of oligodendrocytes by glucose deprivation.

\section{REFERENCES AND NOTES}

1. Adam, P. A. J., Räihä, N.. Rahiala. E., and Kekomäki. M.: Oxidation of glucose and $D-\beta$-OH-butyrate by the early human fetal brain. Acta Paediatr. Scand., 64: 17 (1975)

2. Anderson, J. M., Milner, R. D. G.. and Strich. S. J.: Effects of neonatal hypoglycemia on the nervous system: a pathological study. J. Neurol. Neurosurg. Psychiatry, 30: 295 (1967).

3. Balasubramanian, A. S.. and Bachhawat, B. K.: Sulfate metabolism in brain. Brain Res.. 20: 341 (1970).

4. Banker. B. Q.: The neuropathological effects of anoxia and hypoglycemia in the newborn. Dev. Med. Child. Neurol., 9: 544 (1967).

5. Bhat. N. R., Sarlieve, L. L.. Subba Rao, G., and Pieringer. R. A.: Investigations on myelination in vitro. Regulation by thyroid hormone in cultures of dissociated brain cells from embryonic mice. J. Biol. Chem.. 254: 9342 (1979).

6. Bignami, A., and Dahl. D.: Specificity of the glial fibrillary acidic protein for astroglia. J. Histochem. Cytochem., 25: 466 (1977).

7. Burkart, T., Hofmann. K., Siegrist, H. P.. Herschkowitz, N., and Wiesmann. U. $\mathrm{N}$.: Sulfatide metabolism of mouse cerebrum and cerebellum during development. Experientia (Abstract). 33: 789 (1977).

8. Chase, H. P.. Marlow, R. A., Dabiere, C. S., and Welch, N. N.: Hypoglycemia and brain development. Pediatrics, 52: 513 (1973).

9. Dahlquist, G.., and Persson, B.: The rate of cerebral utilization of glucose, ketone bodies and oxygen: a comparative in vivo study of infant and adult rats. Pediatr. Res.. 10: 910 (1976).

10. Fluge. F.: Neurological findings at follow-up in neonatal hypoglycemia. Acta Paediatr. Scand.. 04: 629 (1975).

11. Fratantoni. J. C., Hall, C. W., and Neufeld, E. F.: The defect in Hurler's and Hunter's syndrome: faulty degradation of mucopolysaccharides. Proc. Natl. Acad. Sci. U.S.A., 60: 699 (1968).

12. Gottlieb, A., Keydar, 1., and Epstein, H. T.: Rodent brain growth stages: an analytical review. Biol. Neonate, 32: $166(1977)$

13. Growdon, W. A., Bratton. T. S.. Houston, M. C., Tarpley, H. L., and Regen, D M.: Brain metabolism in the intact mouse. Am. J. Physiol., 221: 1738 (1971).

14. Herschkowitz. N.. McKhann. G. M., and Shooter, E. M.: Studies of water soluble lipoproteins in rat brain. J. Neurochem.. 15: 161 (1968).

15. Hinegardner. R. T.: An improved fluorometric Assay for DNA. Anal. Biochem. 39: 197 (1971).

16. Herschkowitz. N.: Genetic Disorders of Brain Development: Animal Models. In: G. E. Gault: Biology of Brain Dysfunction. pp. 151-184 (Plenum Press. New York, 1973)

17. Johnson. G. D., Holborow, E. J., and Dorling, J.: Immunofluorescence and immunoenzyme techniques. In: D. M. Weir: Handbook of Experimental Immunology. pp. 15.1-15.30 (Blackwell Scientific Publications, Oxford, 1978.)

18. Jones, E. L., and Smith, W. T.: Hypoglycemic brain damage in the neonatal rat. Clin. Dev. Med. (Lond.), 39/40: 231 (1971)

19. Kahn. K. J., and Myers, R. E.: Insulin induced hypoglycemia in the non-human primate. I. Clinical consequences. In: J. B. Brierley. B. S. Meldrum: Brain Hypoxia. pp. 185-194 (Heinemann, Lid., London, 1971).

20. Koivisto, M., Blanco-Sequeiros, M., and Krause. U.: Neonatal symptomatic and asymptomatic hypoglycemia: a follow up study of 151 children. Dev. Med. Child. Neurol., 14: 603 (1972). 
21. Korinkova, P.. and Lodin, Z.: The metabolism of glucose of nerve cells cultivated under different conditions. Acta Histochem., 56: 47 (1976).

22. Kraus, H., Schlenker. S., and Schwedesky. D.: Developmental changes of cerebral ketone body utilization in human infants. Hoppe-Seyler's Z. Physiol. Chem. 355: 164 (1974).

23. Land, J. M.. Booth. R. F. G., Berger, R., and Clark. J. B.: Development of mitochondrial energy metabolism in rat brain. Biochem. J.. 164: 339 (1977).

24. Levitsky, L. L., Fisher, D. E.. Paton, J. B.. and Delannoy, C. W.: Fasting plasma levels of glucose, acetoacetate, I)-beta-hydroxybutyrate, glycerol, and lactate in the baboon infant: Correlation with cerebral uptake of substrates and oxygen. Pediatr. Res.. 11: 298 (1977).

25. Lewis, L. D., Ljunggren, B., Norberg, K., and Siesjö, B. K.: Changes in carbohydrate substrates, amino acids and ammonia in the brain during insulininduced hypoglycemia. J. Neurochem., 23: 659 (1974).

26. Lewis, L. D., Ljunggren, B., Ratcheson, R. A., and Siesjö, B. K.: Cerebral energy state in insulin induced hypoglycemia, related to blood glucose and to EEG. J. Neurochem., 23: 673 (1974).

27. Lowry, O. H., Rosebrough, N. J.. Farr, A. L., and Randall, R. J.: Protein measurement with the Folin phenol reagent. J. Biol. Chem., 193: 265 (1951).

28. Matthieu, J. M., Widmer. S., and Herschkowitz, N.: Biochemical changes in mouse brain composition during myelination. Brain Res., 55: 391 (1973).

29. Mcllwain, H.. and Bachelard, H. S.: Biochemistry and the central nervous system. (Churchill Livingstone, London, 1971.)

30. Myers. R. E., and Kahn. K. J.: Insulin induced hypoglycemia in the non-human primate. II. Long-term neuropathological consequences. In: J. B. Brierley, B. S. Meldrum: Brain Hypoxia. pp. 195-206 (Heinemann Ltd., London, 1971).

31. Pildes, R. S., Cornblath, M., Warren, I.. Page-El, E., di Menza, S., Merritt, D. M.. and Peeva. A.: A prospective controlled study of neonatal hypoglycemia. Pediatrics, 54: 5 (1974)

32. Raff, M. C., Mirski, R., Fields. K. L., Lisak, R. P., Dorfman, S. H., Silberberg, D. H.. Gregson, N. A., Leibowitz, S., and Kennedy, M. C.: Galactocerebroside is a specific cell-surface antigenic marker for oligodendrocytes in culture Nature (Lond.). 274: 813 (1978).

33. Richterich, R., and Colombo, J. P.: Klinische Chemie. Ed. 4 (S. Karger, Basel, 1978).
34. Sarlieve, L. L.. Neskovic, N. M., Rebel, G., and Mandel, P.: Some properties of brain PAPS-cerebroside sulfotransferase in jimpy and quaking mice. Neurobiology (Copenh.). 2: 70 (1972).

35. Sarlieve. L. L., Neskovic, N. M., Rebel, G., and Mandel, P.: PAPS-cerebroside sulfotransferase activity in developing brain of a neurological mutant of mouse (MSD). Exp. Brain Res., 19: 158 (1974).

36. Sensentrenner. M. Maderspach, K. Latzkovits, L and Jaros, G. G. Neuronal cells from chick embryo cerebral hemisphere cultivated on polylysine-coated surfaces. Dev. Neurosci., I: 90 (1978).

37. Siegrist, H. P., Burkhart, T., Hofmann, K., Wiesmann, U., and Herschkowitz. $\mathbf{N}$ : Influence of reduced cholesterol synthesis on the activity of cerebroside sulfotransferase in cultured glioblastoma cells treated with estradiol. Biochim. Biophys. Acta, 572: 160 (1979).

38. Siegrist, H. P., Jutzi, H., Steck, A. J., Burkhart, T., Wiesmann, U., and Herschkowitz. N.: Age-dependent modulation of 3'-phosphoadenosine-phosphosulfate-galactosylceramide sulfotransferase by lipids extracted from the microsomal membranes and artificial lipid mixtures. Biochim. Biophys. Acta, 489: 58 (1977).

39. Siesjö, B. K.: Brain energy metabolism. (John Wiley \& Sons, Inc., New York. 1978.)

40. Stumpf, B., and Kraus, H.: Regulatory aspects of glucose and ketone body metabolism in infant rat brain. Pediatr. Res., 13: 585 (1979).

41. Wapnir, R. A.: Correlation of blood and brain amino acids in hypoglycemic and normoglycemic rats. Experientia, 32: 1409 (1976).

42. Wiesmann. U. N., Hofmann, K.. Burkhart, Th and Herschkowitz, N.: Dissociated cultures of newborn mouse brain $\mathrm{I}$. Metabolism of sulfated lipids and mucopolysaccharides. Neurobiology (Copenh.), 5: 305 (1975).

43. Wilbur, D. O., and Patel, M. S.: Development of mitochondrial pyruvate metabolism in rat brain. J. Neurochem., 22: 709 (1974).

44. Requests for reprints should be addressed to: PD Dr. K. Zuppinger, UniversitätsKinderklinik. Inselspital, CH-3010 Berne. Switzerland.

45. This research was supported by the Swiss National Science Foundation Grant No 3.834-0.76, 3.768-0.76 and 3.419-0.78.

46. Received for publication January 2, 1980.

47. Accepted for publication July 15, 1980 